\title{
Understanding Livelihood Characteristics and Vulnerabilities of Small-scale Fishers in Coastal Bangladesh
}

\author{
Atiqur Rahman Sunny ${ }^{1,2}$, Shamsul H. prodhan $^{1}$, Md. Ashrafuzzaman ${ }^{1}$, Sharif Ahmed Sazzad ${ }^{3,4}$, \\ Mahmudul Hasan Mithun ${ }^{5}$ K.M. Nadim Haider ${ }^{6}$, Md Tariqul Alam ${ }^{6}$ \\ ${ }^{1}$ Department of Genetic Engineering and Biotechnology, Shahjalal University of Science and Technology, Bangladesh \\ ${ }^{2}$ The WorldFish Center, Bangladesh \\ ${ }^{3}$ Department of Natural Resource Management, Pathfinder Agro and Fisheries Consultation Center, Bangladesh \\ ${ }^{4}$ Department of Sociology, University of Dhaka, Dhaka, Bangladesh \\ ${ }^{5}$ Department of Fisheries Biology and Aquatic Environment, Bangabandhu Sheikh Mujibur Rahman Agricultural University, \\ Bangladesh \\ ${ }^{6}$ Center for Natural Resource Studies (CNRS), Bangladseh \\ ${ }^{7}$ Department of Aquaculture, Sylhet Agricultural University,Sylhet, Bangladesh
}

\begin{abstract}
Small-scale fishers are considered as one of the most vulnerable communities in Bangladesh but very few studies focused on the livelihood sustainability and vulnerabilities of this professional group. A fieldwork in lower Padma and upper Meghna hilsa sanctuaries identifies different livelihood characters and associated vulnerabilities of the fishers. A conceptual framework known as Sustainable Livelihood Approaches (SLA) has been introduced to analyses the qualitative and quantitative data. The insights of the livelihood strategies provide on small-scale fishers and fisheries management have been explained and explored. Fishers are found solely dependent on fishing, economically insolvent and neglected. In addition, some socio-economic abstractions such as low income, credit insolvency, lack of substitute earning flexibility make them more vulnerable. A number of effective suggestions are elicited from fishers' perceptions, the implementation of which is crucial to ensure livelihood sustainability of the small-scale fishers.
\end{abstract}

\section{Keywords: Livelihoods; Sustainability; Vulnerability; Small-scale Fishers; Bangladesh}

Corresponding author:

Atiqur Rahman Sunny

Dept. of Genetic Engineering and Biotechnology, Shahjalal University of Science and Technolohy, Sylhet, Bangladesh

Scientist, WorldFish, Bangladesh and South Asia

Email:atiksunny@yahoo.com 


\section{Introduction}

Bangladesh is a Riverine and located in the South Asia between $20^{\circ} 34^{\prime}$ to $26^{\circ} 38^{\prime} \mathrm{N}$ latitude and $88^{\circ} 01^{\prime}$ to $92^{\circ} 42^{\prime} \mathrm{E}$ longitude with an area of 147570 sq. $\mathrm{km}$ and a population of about 140 million $^{1}$. Inland open water capture fisheries production Bangladesh ranks third and fifth in aquaculture production in the world ${ }^{2}$.At present, Bangladesh ranks 4th in the world in tilapia production and 3rd in $\mathrm{Asia}^{3} .60 \%$ of the total Hilsa (Tenualosa ilisha) in the world also comes from Bangladesh (Sunny et al., 2019a; Sunny et al., 2017).Hilsa supports 11\% of total national production (394, $951 \mathrm{MT}$ ) and contributes $1 \%$ of the Gross Domestic Product (GDP) of Bangladesh ${ }^{4,5,6}$. Hilsa fishery also support livelihood of a large number (3 million) of small-scale fishers of Bangladesh ${ }^{4,7,8}$. Fluctuations in hilsa catch adversely affect the livelihoods small-scale fishers particularly in the coastal Bangladesh ${ }^{4,9}$. Small-scale fishers are considered as one of the most vulnerable communities in Bangladesh although support about 12 million people directly and indirectly ${ }^{10}$. They live from hand to mouth and are recognized as the poorest of the poor $^{2,11,12}$. Most of the fishers are landless, poor and fully dependent on fishing for their livelihoods. Some socioeconomic constraints like increasing fishers number, low income, lack of alternative income generating activities, loan complexity, piracy and price hike make their life miserable ${ }^{4,13,14}$. Annual per capital income (BDT 2,442) of the fishers is almost $70 \%$ lower than the per capital income of the country as a whole ${ }^{4,11}$. Hilsa fishers suffer most among the smallscale fishers due to restriction on catching hilsa during ban period, frequent natural calamities and seasonality $5,15,16,17$.

Vulnerability in the literature of both disaster and development, a widely used term has linked to poverty, both as a causal factor and a direct product. It can be defined as the universal level of exposure to risks, shocks, stresses, and food insecurity ${ }^{4,18,19}$. All these factors affect the sustainability of livelihood. A livelihood will be sustainable if it can cope with and recover from stress, shocks, maintain or enhance its capabilities and assets for present and next generation. Livelihood assets could be categorized as natural, physical, human, financial and social capital $^{4,20,21}$. Human capital of the small-scale fishers includes the skills, working ability, knowledge, and good health. Natural capital includes land, water, wild fry, fish, molluscs and all the fisheries products. Fishers' incomes and savings are considered as the financial capital. Physical capital includes house, fishing gear, boat, road and communication system, electricity, 
water supply, sanitary and existing health facilities. Social capital includes credit, relationship and cooperation, cultural norms and sharing of knowledge $\mathrm{e}^{1,4}$.

Shariatpur is a gathered place for small-scale fishers due to presence of both the mighty Padma and Meghna River. The Padma covers Naria and Bhedargaj upazila and the Meghna covers only Bhedarganj. Bhedarganj is blessed with Riverine fisheries resources and the major catches are hilsa, poa, icha, taposhi, bata, pangas etc ${ }^{4}$. For a long time, different types of fishing gears have been used in the sanctuaries of the Padma and Meghna. The intensity of use of any type of gear in the sanctuaries depends on the intensity of target fish population found in the River. Some gears are selected for specific species whereas other use for a number of species during operation. The choice of nets also depends on the case of operation and varies in the different places of the same River ${ }^{11,22,23}$. People of the Riverside particularly depend on hilsa fishing to support their livelihood.

Sustainable livelihood is pre-requisite to achieve the Millennium Development Goals $(\mathrm{MDGs})^{24,25}$. Adequate and precise information on the livelihood characteristics of the target community is essential and decisive for decision making but lack of required information of economically backward small-scale fishers is the major obstacles to the successful development of their livelihoods ${ }^{1,4}$. Considering the above facts, the present study is carried out to assess the livelihood sustainability analyzing different livelihood assets and associated vulnerabilities of the small-scale fishers of the hilsa sanctuary in the Padma and Meghna River.

\section{Materials and Methods}

\subsection{Study sites}

The study was conducted in the fishing communities of Char Bhaga union in Bhedarganj upazila under Shariatpur district (Figure 01). The upazila was located in between $23^{\circ} 08^{\prime}$ and $23^{\circ} 24^{\prime}$ north latitudes and in between 90²3' and 90 36' east longitudes. Reasons behind selecting the communities were presented below-

- The suitability of the area to meet the study objectives

- Location on the bank of the lower Padma River and access to Meghna River

- Presence of fish landing center (Mach ghat) to fishing community. 
- Availability of very poor, ladless fishing communities.

- Involvement of large number people in fishing.

- Indiscriminate use illegal fishing gear.

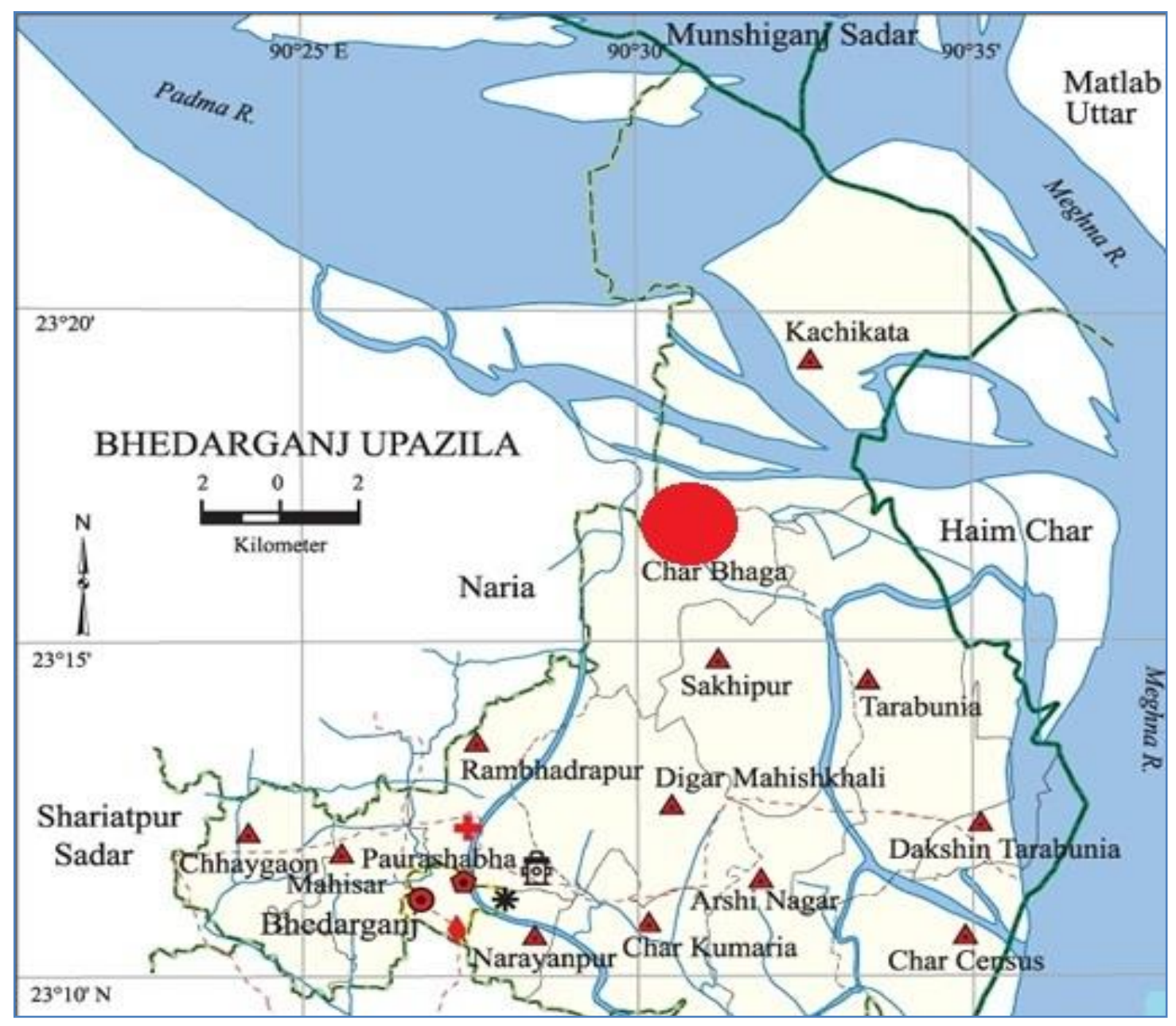

Figure 01: Map of the Study area

\subsection{Formulation of questionnaire}

To identify the fishers' socio-economic condition a scheduled interview were conducted for gathering information about fishers' demography, health, sanitation, household, income, credit, savings, literacy and land ownership etc. A structured questionnaire was designed by following De Vaus ${ }^{26}$ that also included socio-economic parameters, the living and survival strategies to understand fisher's condition. 


\subsection{Questionnaire interviews (QI)}

Random sampling method was adopted for questionnaire interviews. There were almost 90 fishermen randomly selected for interviews from the study area. They were interviewed by their houses and Riversides only when they were available and per interview were taken almost half an hour by each fisher.

\subsubsection{Focus group discussion (FGD)}

Participatory Rural Appraisal (PRA) tool as FGD was used in this study. Focused group discussion was conducted towards the fishers in order to find out socio-economic condition and existing fishing systems.

\subsubsection{Cross-cheek interviews}

Upazila Fisheries Officers (UFO) and other associated personnel were selected for cross-check interview

\subsection{Secondary data collection method}

The data was collected from various secondary sources to complete the study. Various scholarly articles and relevant literature were quoted from relevant technical and newspaper reports. All of these aggregated data were comprehensively reviewed; synthesized and relevant data were used in this study.

\subsection{Data processing, analysis and presentation}

Interviews and data from FGD were coded and inserted MS Excel (Version 2016) for processing and analysis of tables, figures etc. for results presentation. The Department for International Development (DFID) sustainable livelihoods framework ${ }^{1,20}$ was applied to shape the qualitative and quantitative data.

\subsubsection{Sustainable Livelihoods Approach (SLA)}

Livelihood become sustainable when it could cope with and overcome stresses, shocks, and maintained capabilities and assets for present and future generation ${ }^{1,4}$. The concept of a 'livelihood' combined together the critical factors that affect the strength and weakness of 
individual or family survival strategies ${ }^{27}$. The fishers had more or less various type assets as defined by the DFID sustainable model which could be classified as human, natural, financial, social and physical capital ${ }^{28}$. The sustainable livelihoods framework as whole can reflect the risk that the poor might be very vulnerable, the assets and resources that could help them to improve and survive, and the policies and institutions that affected their livelihoods ${ }^{20}$. The SLA framework showed that in different context, the constraints of different livelihood assets were achieved that were consolidated following different livelihood strategies.

\section{Results and Discussion}

\subsection{Social profile of the fishers}

Socio-demographic status of the fishing communities was quite different from the other professional communities. There were 1500 people lived in 185 households $(\mathrm{HH})$ in the Charvaga village. Among $185 \mathrm{HH}, 102 \mathrm{HH} \pm 2 \mathrm{HH}$ (mean \pm standard deviation) were intensively involved in fishing and $83 \mathrm{HH} \pm 3 \mathrm{HH}$ were involved both in fishing and small business. Most of the fishers $(84 \% \pm 2 \%)$ provided hired labor and had no fishing net and boat of their own. All the fishers lived below the poverty line. The percentage of extreme poor (land size 0 decimal), poor (land size $<5$ decimal) and moderately poor (land size $>5$ decimal) was $25 \% \pm 3 \%, 51 \% \pm 4 \%$ and $18 \% \pm 1 \%$ respectively (Table 1 ). There were 130 nomads and 30 gypsies living in this area. The nomadic families stayed here for six to seven months in a year and worked as day laborers in their own areas for the remaining five to six months. Among the locals, only the men fishers were found in fishing but gypsy women were seen fishing in the Padma River. Women of fishing communities were not self-reliant. Women had less decision making capacity in their family and had to depend on their male family members. Community people were at risk due to natural disasters as well as low income and lack of employment which hindered livelihood sustainability. Livelihood means the ability, resources, assets and activities that are needed to make a living ${ }^{1,4}$.The livelihood assets of the fishers could be categorized as human, natural, financial, social and physical as defined by the DFID that indicated the actual socioeconomic status of this marginalized vulnerable community ${ }^{4,29}$. 
Table 1: Social profile of the fishers

\begin{tabular}{lll}
\hline Variable & Status & Mean $( \pm$ SD) \\
\hline Population & Total number & 1500 \\
House hold & Total number & 185 \\
& Number of exclusive fisher & $102(2)$ \\
& Number of other & $83(3)$ \\
Gipsy & Number of HH & 30 \\
Nomad & Number of HH & 130 \\
& Temporary period (month) & $6(1.2)$ \\
Land size (decimal) & Extreme poor & 0 \\
& Poor & $<5(0.5)$ \\
\multirow{2}{*}{ Women's decision } & making & Yes \\
capacity & No & $1 \%$ \\
Climatic hazards affect daily & Yes & $99 \%$ \\
life & No & $95 \%$ \\
\hline
\end{tabular}

\subsection{Livelihood assets of the small-scale fishers}

\subsubsection{Human capital}

\subsubsection{Fishers' type and fishing duration}

A large number of fishers used to fish in the Padma sanctuary and adjacent Meghna River. Fishers could be classified into three groups based on their practice named as professional fishers, seasonal fishers and subsistence fishers. Professional fishers depended on fishing almost round the year for their livelihood. Seasonal fishers caught fish only a particular time of the year which kept them engaged in other income generating activities to support their life. Subsistence fishers caught fish mainly for their home consumption to meet family demand and sold remaining (if have) to add money in family income. They study found $55.5 \% \pm 2 \%$ (mean \pm standard deviation) were professional following seasonal $(35 \% \pm 3 \%)$ and subsistence $(55.5 \pm 2)$. Rana et al. ${ }^{11}$ found $91 \%$ professional fishers and 9\% seasonal fishers in the Meghna River. 
Professional and seasonal fishers were known to go fishing both day and night. Subsistence fishers were only seen fishing during the day. The average fishing time was recorded for Professional fishers $12 \pm 2$ hours, $15 \pm 2$ hours for seasonal fishers and $4 \underline{1}$ hours for subsistence fishers. Average fishing duration of the fishers of the Meghna River was recorded15 hours in a day (24 hours) ${ }^{11}$.

\subsubsection{Marital status and family types}

Marital and family background was important to assess socioeconomic status, live to sustainability and disaster susceptibility. The study identified $55 \% \pm 2.2 \%$ (mean \pm standard deviation) were married following unmarried $(40 \% \pm 1.4 \%)$ and divorced $(5 \% \pm 0.4 \%)$. There were no oppressed persons in the study area. Family type varied from joint to nuclear. It was found that $30 \% \pm 1.5 \%$ of the people lived with joint families and $70 \% \pm 4.2 \%$ lived with nuclear families in this region. The nuclear family was very popular due to its abundance of movement and economic opportunities, better clothing, better education, and women authority. The family size was $5 \pm 1.1$ persons in nuclear families and $10 \pm 2.2$ persons in joint families. $5.1 \pm 2.11$ members in nuclear families and 10 \pm 2.05 members in joint families of the fishers of the Padma River in $5^{\text {th }}$ hilsa sanctuary of Bangladesh was reported earlier ${ }^{4}$. Another study found that $78 \%$ had average 5, 14\% had 3 members while $8 \%$ had 9 members in their family among the fishers of the Padma River in Rajshahi region which also reflected the findings of this study.

\subsubsection{Age distribution and fishing experience}

The age structures of the fishers were an important indicator in taking decision and maintaining a profitable fishing operation. $40 \% \pm 3.2 \%$ (mean \pm standard deviation) of the studied areas was in the age group of $41-50$ years. It was found that $20 \%, 20 \%, 10 \%, 10 \%$ and $0 \%$ of fishermen were belong to age group in 21-30,31-40, 51-60, and 61-70 years respectively. The result showed that 41-50 years age group was considered more active due to their physical strength and young generation was less interested in fishing. The finding of the study was merely similar with another earlier study who reported most of the fishers in 31-50 years age group in their study respectively in the Padma (in $5^{\text {th }}$ hilsa sanctuary), Padma (outside the hilsa sanctuary), Meghna and Kirtonkhola River ${ }^{4,11,30}$. The average fishing year was $15 \pm 3$ years with a minimum of 2.5 \pm 1.2 and a maximum of $17 \pm 3$ years 


\subsubsection{Religious status}

In the present study $100 \%$ of the fishers was Muslim as the entire population of this village was Muslim. Religions and castes played a vital role in fishing and trading of small-scale fishers. Currently the involvement of Hindus in fishing in the Padma sanctuary was increasing. ${ }^{4}$

\subsubsection{Educational and literacy status}

A minimal educational background was necessary for success in the use of natural resources of Padma sanctuary but the state of education in the study area was not so good. Majority of the small-scale fishers were either illiterate or only can sign. Fishers were classified into four groups based on their level of education. Among the fishers $50 \% \pm 2.5 \%$ (mean \pm standard deviation) had no education (illiterate), $30 \% \pm 1.5 \%$ could only sign, $10 \% \pm 0.2 \%$ had primary level (class 1 to 5 ) and $10 \% \pm 0.2 \%$ had secondary level education (class 6 to 10 ). Poor socioeconomic status $(55 \pm 1.5)$, early fishing involvement $(30 \pm 1.4)$, unavailability of educational institution in the surrounding areas $(15 \pm 0.4)$ were the main responsible factors of low literacy rate. A previous report mentioned $88 \%$ fishers were illiterate $^{31}$.

\subsubsection{Nutritional status}

The nutritional status of the fishers was not satisfactory. Fisher's families did not have appropriate knowledge about the nutritional quality of food and the importance of balanced $\operatorname{diet}^{1,4} \cdot 68.5 \pm 3.3$ (mean \pm standard deviation) did not eat enough and nutrition sensitive meal three times a day. They sold their fish to get more money. Their main diet is only vegetables with rice most of the times $(25 \pm 2)$ in a month that induced malnutrition and disease susceptibility. Same scenario was also found health and nutritional misery among the marginal fish farmers of Barisal region ${ }^{4,32}$. Common diseases of the small-scale fishers were headache $(75 \pm 5)$, flu $(68 \pm 5)$ and fever $(54 \pm 5)$.

\subsubsection{Physical capital}

\subsubsection{Housing and infrastructure}

In the study area, houses of the community were of two main types named as katcha-houses and semi pacca houses. Katcha-houses were made of bamboo spill and tin with mud flooring and semi pacca- made of wood and tin with cement floor. In this community $90 \% \pm 4.5 \%$ (mean \pm standard deviation) of housing structures were kacha, and only $10 \% \pm 0.5 \%$ were semi pacca. 
Road and transportation system was not developed. There was only a local road to communicate with upazila and district city. The status of other roads which were used in local communication among the communities was very poor.

\subsubsection{Available fishing gears}

Fishers used different fishing gears to catch different fishes. The use of fishing gears also varied from season to season depending on availability of fish.A total of 10 types of fishing gears in 3categories like gulti jai(drift gill net), current jal (drift gill net), ber jal (drift gill net), pangaissha jal (drift gill net), moia jal(seine net), mushuri jal(seine net), gachi jal(seine net), boro chai (fishing trap), dar chai (fishing trap) and gura chai(fishing trap) were found in this area(Table 2). Among the gears only gultijal and pangaissha jal were legal and others were illegal. Berjal, moiajal,mushurijal and gachijal were used round the year and remaining were seasonal. noticed Nine (9) categories of fishing gears in the Pagla River of Kishoregonj that included gill net, seine net, lift net, set bag net, push net, hook and line, long line, spears and traps were noticed in a previous study ${ }^{33}$.

Table 2: Fishing gears used by the fishers

\begin{tabular}{|c|c|c|c|c|c|}
\hline Gear & Categories & $\begin{array}{l}\text { Operating } \\
\text { man power }\end{array}$ & Specification & Status & Operating period \\
\hline Gultijal & Drift gill net & $4-10$ & $\begin{array}{l}\text { Mesh size }(4.5 \\
\mathrm{cm})\end{array}$ & Legal & $\begin{array}{l}\text { August, September, } \\
\text { January, February, } \\
\text { March }\end{array}$ \\
\hline Current jal & Drift gill net & $2-5$ & Mesh size $(3 \mathrm{~cm})$ & illegal & Round the year \\
\hline $\begin{array}{l}\text { Pangaisshaja } \\
1\end{array}$ & Drift gill net & $2-5$ & Mesh size $(5 \mathrm{~cm})$ & Legal & $\begin{array}{l}\text { March, April, } \\
\text { October, } \\
\text { November, } \\
\text { December }\end{array}$ \\
\hline Berjal & Seine net & $4-10$ & Mesh size $(.5 \mathrm{~cm})$ & illegal & Round the year \\
\hline Moiajal & Seine net & $4-10$ & Mesh size $(.5 \mathrm{~cm})$ & illegal & Round the year \\
\hline Gachijal & Seine net & $3-7$ & Mesh size $(.4 \mathrm{~cm})$ & illegal & Round the year \\
\hline Mushurijal & Seine net & $3-7$ & Mesh size $(.4 \mathrm{~cm})$ & illegal & Round the year \\
\hline Boro chai & Fishing trap & $1-2$ & $\begin{array}{l}\text { large in size( } \\
\text { mouth } 6 \mathrm{ft} \text {. in } \\
\text { length), } \\
\text { exclusively used } \\
\text { for large sized }\end{array}$ & illegal & $\begin{array}{l}\text { March, April, } \\
\text { October, } \\
\text { November, } \\
\text { December }\end{array}$ \\
\hline
\end{tabular}




\section{fish; especially}

pangas

$\begin{array}{llll}\text { Dar chai } \quad \text { Fishing trap } \quad 1-2 & \begin{array}{l}\text { Small in size, } \\ \text { approximately } 3 \\ \text { ft. in length }\end{array} & \text { illegal } & \text { March, April, } \\ & & \text { October, } \\ & & \text { November, } \\ & & \text { December }\end{array}$

Gura Chai Fishing trap 1-2 Exclusively used Illegal March, April, for small fish with October, mouth size of $1 \mathrm{ft}$. November,

December

\subsubsection{Treatment facility}

Medical facilities were also very limited in this area. They didn't have access to medicine and necessary treatment due to the absence of specialized hospital at the nearest distance. Fishers took immediate treatment from quacks. The study found $60 \%$ of fishers took allopathic, $20 \%$ homeopathic, and rest $20 \%$ take herbal and other treatment.

\subsubsection{Drinking water facility}

The study found that $80.2 \% \pm 2.1 \%$ (mean \pm standard deviation) of the fishermen used tube-well water for drinking. Among them $9 \% \pm 0.2 \%$ fishers used their own tube-well, $27 \% \pm 2.2 \%$ used government tube-well, and $60 \% \pm 2.5 \%$ used neighbors' tube-well. Remaining $10 \% \pm 0.5 \%$ of fishers used well or Indira (specialized well in Bangladesh) water for drinking, $10 \% \pm 1.1 \%$ of the fishers used ring-well water for drinking purpose. Those who used safe tube well water used it not only for drinking, but also for cooking and bathing. It was reported that $94.44 \%$ nonmigratory fishers of the Padma River used tube-wells as a source of drinking water while only $10.53 \%$ migratory fishers of the Padma River used nearby tube-well water whereas, the greater proportions $(89.47 \%)$ used River water for drinking and other purposes ${ }^{24}$.

\subsubsection{Sanitary status}

The people were aware of sanitary problems and all the people were very keen to ensure safe sanitary facilities and used sanitary latrine. It was observed that majority (102) of the people had katcha (earthen) toilet and 83 respondents had semi-pacca (semi cemented) toilet. They observed 
in the fishers $92 \%$ fishers of the Padma River in northern Bangladesh used unhygienic toilet which indicated the poor sanitary status ${ }^{25}$.

\subsubsection{Electricity facility}

The power situation in the fishing community was very fragile. Electricity was available to only $30 \% \pm 3.5 \%$ (mean \pm standard deviation) people. $70 \% \pm 6.3 \%$ of the people in this community used solar power as a source to illuminate their homes. An earlier study mentioned the opposite findings and observed electricity connection in most fishers' house ${ }^{10}$.

\subsubsection{Natural capital}

\subsubsection{Land properties}

The number of landless fishers was high in the Padma sanctuary. Extreme poor fishers were landless. Poor fishers had $<5$ decimal and moderately poor fishers $>5$ decimal land.

\subsubsection{Biodiversity status}

The sanctuary of Padma was situated in coastal region but most of the time the salinity range was close to zero. So, the fish biodiversity of this region was a combination of estuarine and freshwater fishes. The study recorded 71 fish species in the Padma sanctuary area (Table 3). Hilsa (Tenualosailisha) was the main commercial species of the Padma sanctuary.A total of 35\% of recorded fishes were in cypriniformes, following siluriformes (24\%), perciformes (16\%),synbranchiformes (6\%), channiformes(5\%)and clupiformes (4\%).Beloniformes, channiformes, $\quad$ osteoglossiformes $\quad$ represented $3 \%$ each andcyprinodontiformes, anguilliformes, gasterosteiformes,pleuronectiformes, tetraodontiformes represented $1 \%$ each (Figure 2 ).

Table 3: List of available fish species

\begin{tabular}{lllll}
\hline $\begin{array}{l}\text { Sl. } \\
\text { No }\end{array}$ & Order & $\begin{array}{l}\text { Scientific identity of the taxon } \\
\text { with author }\end{array}$ & $\begin{array}{l}\text { Vernacular or } \\
\text { local } \\
\text { Bengali name }\end{array}$ & $\begin{array}{l}\text { Common or } \\
\text { English name }\end{array}$ \\
\hline & & & Kathal pata & Pan sole \\
\hline 1. & Pleuronectiformes & $\begin{array}{l}\text { Brachirus pan (Hamilton, 1822) } \\
\text { Salmostoma phulo(Hamilton, } \\
1822)\end{array}$ & Fulchela & Flying barb \\
2. & Cypriniformes & & \\
\hline
\end{tabular}




\begin{tabular}{|c|c|c|c|c|}
\hline 3. & Cypriniformes & Esomus danrica (Hamilton, 1822) & Darkina & Flying barb \\
\hline 4. & Cypriniformes & Rasbora rasbora (Hamilton, 1822) & Darkina & Flying barb \\
\hline 5. & Cypriniformes & Chela labuca (Hamilton, 1822) & Labuca & Hatchet fish \\
\hline 6. & Cypriniformes & $\begin{array}{l}\text { Aspidoparia morar (Hamilton, } \\
1822 \text { ) }\end{array}$ & Morari & River stone carp \\
\hline 7. & Cypriniformes & $\begin{array}{l}\text { Megarasbora elanga (Hamilton, } \\
\text { 1822) }\end{array}$ & Along & Bengala barb \\
\hline 8. & Cypriniformes & $\begin{array}{l}\text { Barilius bendelisis (Hamilton, } \\
1807 \text { ) }\end{array}$ & Joia & Hamilton's barila \\
\hline 9. & Cypriniformes & $\begin{array}{l}\text { Osteobrama cotio (Hamilton, } \\
1822 \text { ) }\end{array}$ & Dhela & Cotio \\
\hline 10. & Cypriniformes & Puntius sarana (Hamilton, 1822) & Sar punti & Olive barb \\
\hline 11. & Cypriniformes & Puntius chola (Hamilton, 1822) & Chala punti & Chola barb \\
\hline 12. & Cypriniformes & Puntius guganio (Hamilton, 1822) & Mola punti & Glass-barb \\
\hline 13. & Cypriniformes & $\begin{array}{l}\text { Puntius conchonius (Hamilton, } \\
\text { 1822) }\end{array}$ & Kancha npunti & Rosy barb \\
\hline 14. & Cypriniformes & Puntius ticto (Hamilton, 1822) & Tit punti & Ticto barb \\
\hline 15. & Cypriniformes & Puntius sophore (Hamilton, 1822) & Jat punti & Pool barb \\
\hline 16. & Cypriniformes & Puntius terio (Hamilton, 1822) & Teri punti & One spot barb \\
\hline $\begin{array}{l}17 . \\
18 .\end{array}$ & $\begin{array}{l}\text { Cypriniformes } \\
\text { Cypriniformes }\end{array}$ & $\begin{array}{l}\text { Cirrhinus reba (Hamilton, 1822) } \\
\text { Devario devario(Hamilton, 1822) }\end{array}$ & $\begin{array}{l}\text { Reba } \\
\text { Baspata }\end{array}$ & $\begin{array}{l}\text { Reba carp } \\
\text { Bengal danio }\end{array}$ \\
\hline 19. & Cypriniformes & $\begin{array}{l}\text { Lepidocephalus guntea (Hamilton, } \\
1822 \text { ) }\end{array}$ & Gutum & Guntea loach \\
\hline 20. & Cypriniformes & Labeo rohita (Hamilton, 1822) & Rui & Rohu \\
\hline 21. & Cypriniformes & Catla catla (Hamilton, 1822) & Catla & Catla \\
\hline 22. & Cypriniformes & Cirrhinu scirrhosus (Bloch, 1795) & Mrigal & Mrigal carp \\
\hline 23. & Cypriniformes & Labeo calbasu (Hamilton, 1822) & Kala Baush & Karnataka labeo \\
\hline 24. & Cypriniformes & Labeo bata (Hamilton, 1822) & Bata & Bata labeo \\
\hline 25. & Cypriniformes & $\begin{array}{l}\text { Amblypharyngodon mola } \\
\text { (Hamilton, 1822) }\end{array}$ & Mola & Molacarplet \\
\hline 26. & Cypriniformes & Raiamas bola (Hamilton, 1822) & Bhol & $\begin{array}{l}\text { Trout barb, Indian } \\
\text { trout }\end{array}$ \\
\hline 27. & Siluriformes & $\begin{array}{l}\text { Eutropiichthys vacha(Hamilton, } \\
\text { 1822) }\end{array}$ & Bacha & Schilbi \\
\hline 28 & Siluriformes & $\begin{array}{l}\text { Eutropiichthys murius (Hamilton, } \\
\text { 1822) }\end{array}$ & Muri bacha & Muriusvacha \\
\hline \multirow[t]{2}{*}{29.} & Siluriformes & Ompok Pabda(Hamilton, 1822) & Modhu Pabda & Pabda catfish \\
\hline & Siluriformes & Ompok Pabo(Hamilton, 1822) & Pabda & Pabo catfish \\
\hline
\end{tabular}




\begin{tabular}{|c|c|c|c|c|}
\hline 30. & Siluriformes & $\begin{array}{l}\text { Wallago attu (Bloch \& Schneider, } \\
\text { 1801) }\end{array}$ & Boal & Freshwater shark \\
\hline 31. & Siluriformes & Silonia silondia (Hamilton, 1822) & Shilong & Silond catfish \\
\hline 32. & Siluriformes & $\begin{array}{l}\text { Pangasius pangasius (Hamilton, } \\
1822 \text { ) }\end{array}$ & Pangus & Pangas catfish \\
\hline 33. & Siluriformes & Ailia coila (Hamilton, 1822) & Kajuli & Gangetic catfish \\
\hline 34. & Siluriformes & Rita rita (Hamilton, 1822) & Rita & $\begin{array}{l}\text { Rita, Striped } \\
\text { catfish }\end{array}$ \\
\hline 35. & Siluriformes & Sperata aor (Hamilton, 1822) & Ayre & $\begin{array}{l}\text { Long-whiskered } \\
\text { catfish }\end{array}$ \\
\hline 36 & Siluriformes & Sperata seenghala (Sykes, 1839) & Guizza ayre & Giant River catfish \\
\hline 37 & Siluriformes & Mystus vitatus(Bloch, 1794) & Tengra & $\begin{array}{l}\text { Stripped dwarf } \\
\text { catfish }\end{array}$ \\
\hline 38. & Siluriformes & Mystus cavasius (Hamilton, 1822) & Golsha Tengra & Gangetic mystus \\
\hline 39. & Siluriformes & Mystus bleekeri (Day, 1877) & Golsha Tengra & Catfish \\
\hline 40. & Siluriformes & Mystus tengara(Hamilton, 1822) & Bazari Tengra & Tengaramystus \\
\hline 41. & Siluriformes & $\begin{array}{l}\text { Clupisoma garua (Hamilton, } \\
\text { 1822) }\end{array}$ & Garua & River catfish \\
\hline 42 & Siluriformes & Chaca chaca(Hamilton, 1822) & Chaka & Squarehead catfish \\
\hline 43 & Siluriformes & $\begin{array}{l}\text { Pseudeutropius atherinoides } \\
\text { (Bloch, 1794) }\end{array}$ & Batasi & Indian potasi \\
\hline 44. & Tetraodontifomes & $\begin{array}{l}\text { Tetraodon cutcutia (Hamilton, } \\
1822 \text { ) }\end{array}$ & Potka & $\begin{array}{l}\text { Ocellated } \\
\text { pufferfish }\end{array}$ \\
\hline 45. & Beloniformes & $\begin{array}{l}\text { Xenentodon cancila (Hamilton, } \\
1822 \text { ) }\end{array}$ & Kakila & Freshwater garfish \\
\hline 46. & Beloniformes & $\begin{array}{l}\text { Hyporhamphus limbatus } \\
\text { (Valenciennes, 1847) }\end{array}$ & Ekthota & $\begin{array}{l}\text { Congaturi } \\
\text { Halfbeak }\end{array}$ \\
\hline 47. & $\begin{array}{l}\text { Cyprinodontiform } \\
\text { es }\end{array}$ & $\begin{array}{l}\text { Aplocheilus panchax (Hamilton, } \\
\text { 1822) }\end{array}$ & Kanpona & Blue Panchax \\
\hline 48. & Channiformes & Channa punctatus (Bloch, 1793) & Taki & Spotted snakehead \\
\hline 49. & Channiformes & $\begin{array}{l}\text { Channa orientalis(Bloch \& } \\
\text { Schneider, 1801) }\end{array}$ & Raga/Cheng & $\begin{array}{l}\text { Walking } \\
\text { snakehead }\end{array}$ \\
\hline 50 & Clupiformes & Tenualosa ilisha (Hamilton, 1822) & Ilish & Hilsa shad \\
\hline 51. & Clupiformes & Corica soborna (Hamilton, 1822) & Kachki & $\begin{array}{l}\text { The Ganges River } \\
\text { Sprat }\end{array}$ \\
\hline 52. & Clupiformes & Setipinna phasa (Hamilton, 1822) & Phasa & $\begin{array}{l}\text { Gangetic hairfin } \\
\text { anchovy }\end{array}$ \\
\hline 53. & Synbranchiformes & $\begin{array}{l}\text { Macrognathus aculeatus (Bloch, } \\
\text { 1786) }\end{array}$ & Tara baim & Lesser spiny eel \\
\hline 54. & Synbranchiformes & $\begin{array}{l}\text { Mastacembelus } \\
\text { armatus (Lacepede, 1800) }\end{array}$ & Baim & Spiny eel \\
\hline 55. & Synbranchiformes & Mastacembelus pancalus & Guchi baim & Spiny eel \\
\hline
\end{tabular}


(Hamilton, 1822)

56. Synbranchiformes Monopterus cuchia (Hamilton, Kuchia Gangetic mud eel 1822)

57. Osteoglossiformes Notopterus notopterus (Pallas, Foli $\quad$ Bronze featherback 1769)

58. Osteoglossiformes Chitala chitala (Hamilton, 1822) Chital Clown knifefish

59. Perciformes

Colisa fasciatu(Bloch \&

Khalisha

Banded gourami

60. Perciformes

Schneider, 1801)

61. Perciformes

Colisa lalia(Hamilton, 1822)

Lalkholisha

Dwarf gourami

Anabas testudineus (Bloch, 1792)

Koi

Climbing perch

62. Perciformes

Chanda nama Hamilton, 1822

Nama Chanda

Elongate Glass

Perchlet

63. Perciformes

Parambassis lala (Hamilton,

Lal Chanda

64. Perciformes 1822)

Highfin Glassy

Perchlet

Parambassis ranga (Hamilton, Ranga chanda

Indian glassy fish

65. Perciformes 1822)

66. Perciformes

Chanda beculis (Hamilton, 1822)

Chanda

Glossogobius giuris (Hamilton, Bele

Himalayan glassy perchlet 1822)

67. Perciformes

Rhinomugil corsula(Hamilton, 1822)

Khorsula

Freshwater goby

68. Perciformes

Nandus nandus(Hamilton, 1822)

Bheda

Mud perch

69. Perciformes

Brachygobius nunus (Hamilton, 1822)

Nuna Baila

Bumblebee goby

70. Gasterosteiformes

Microphis cuncalus (Hamilton, 1822)

Kumirer khil

Crocodile-tooth pipefish,

71. Anguilliformes

Pisodonophis boro (Hamilton, 1822)

Bamosh

Rice-paddy eel, 


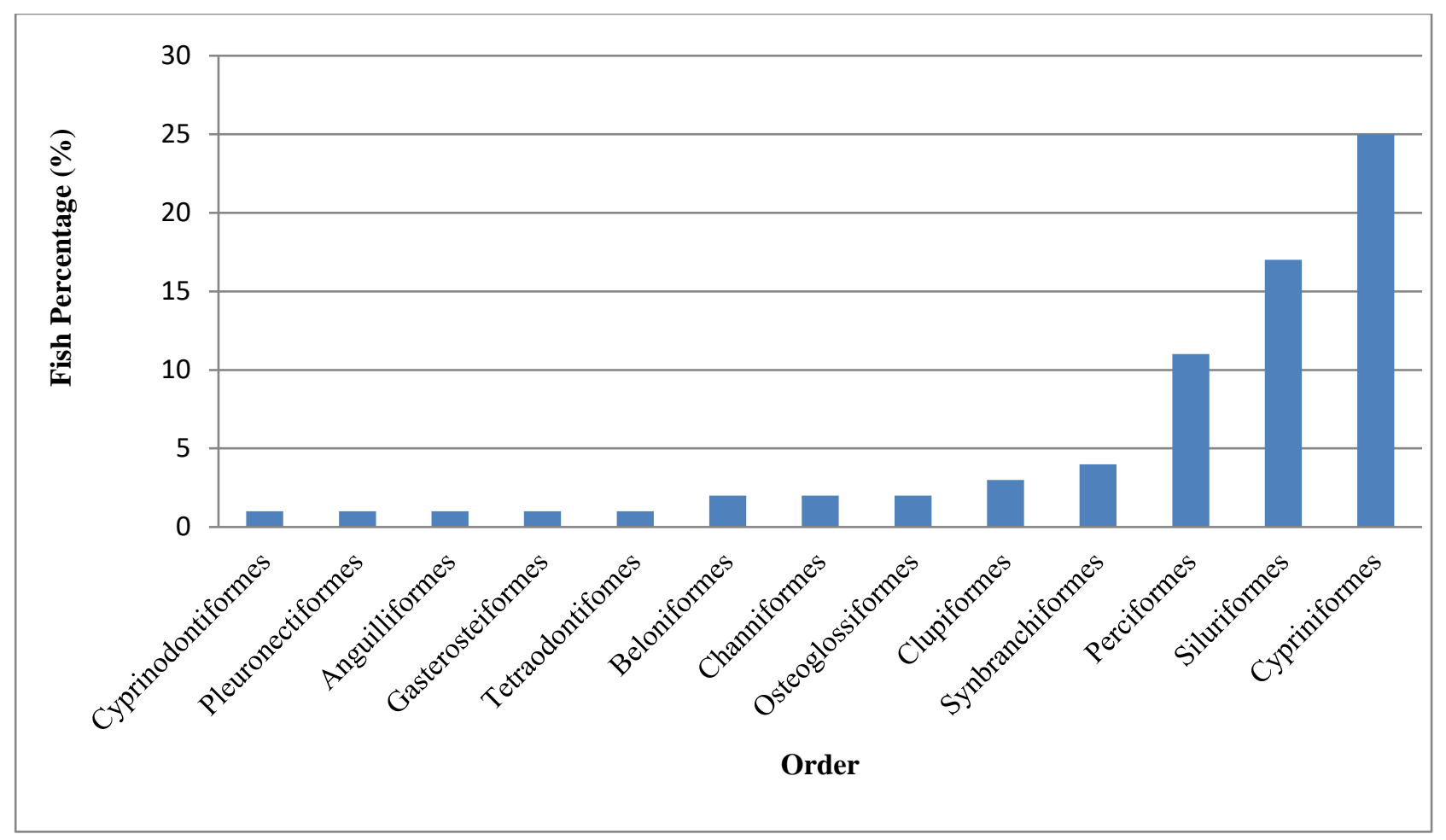

Figure 2: Percentage of different orders of recorded fishes

\subsubsection{Financial capital}

\section{Income status}

The level of income of a household determined the socio-economic status in a society ${ }^{35}$.In most cases, the income of the fishers in Bangladesh was below poverty line $5,11,14$. The earnings of the fishers were comparatively lower than those of other marginalized communities. The average monthly income varied from $3000 \pm 255$ BDT to $7500 \pm 495$ BDT. Fishers in the South and Southeast Asia could be considered as the poorest of the poor ${ }^{10}$. Fishers had very rare alternative source of income for living other than fishing and selling ${ }^{36}$. They rented their labor on the agricultural land or spent time lazily and women raised chickens and ducks on a limited scale. Lack of capital, rearing space and skilled were their main problem faced by the fishers' women (Table 4). Outbreak of contagious diseases also discouraged fishing households to be involved in pet rearing. The study identified the necessity of diversified Alternative Income Generating Activities (AIGAs) to improve the living standards of the fishers. 
Table 4: Existing AIGAs for women and men of fishing households

\begin{tabular}{|c|c|c|c|}
\hline Existing AIGA & Involvement & Inducing factors & Challenges \\
\hline $\begin{array}{l}\text { Agricultural } \\
\text { activities }\end{array}$ & Man & 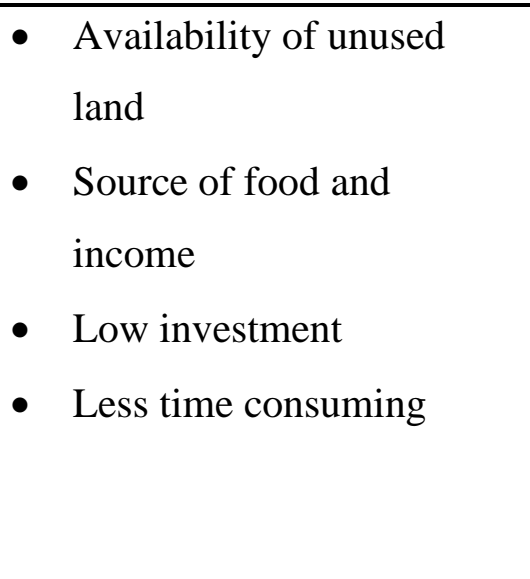 & $\begin{array}{l}\text { - Limited working } \\
\text { scope } \\
\text { - Lack of modern } \\
\text { technology } \\
\text { - Lack of } \\
\text { communication } \\
\text { with Dept. of } \\
\text { Agriculture }\end{array}$ \\
\hline Sewing & Women & $\begin{array}{l}\text { - Need less investment } \\
\text { - Women can do by } \\
\text { maintaining family } \\
\text { - Regular income for day to } \\
\text { day life }\end{array}$ & $\begin{array}{l}\text { - Lack of money to } \\
\text { buy or repair } \\
\text { machine }\end{array}$ \\
\hline .Hen rearing & Women & $\begin{array}{l}\text { - Source of income } \\
\text { - Provide egg and meat for } \\
\text { home consumption } \\
\text { - Increase savings }\end{array}$ & $\begin{array}{l}\text { - Contagious } \\
\text { diseases } \\
\text { - Lack of rearing } \\
\text { place }\end{array}$ \\
\hline Duck rearing & women & $\begin{array}{l}\text { No need of artificial feed } \\
\text { due to having vast water } \\
\text { resources } \\
\text { - } \text { Require less monitoring } \\
\text { - Source of income }\end{array}$ & $\begin{array}{l}\text { - Contagious } \\
\text { diseases }\end{array}$ \\
\hline
\end{tabular}

\subsubsection{Social capital}

\section{Credit operation}

The study found $93 \% \pm 5 \%$ (mean \pm standard deviation) took loan but the institutional credit facilities were very limited due to lack of resource or property to mortgage. Fishers took loan to 
feed their families and buy fishing equipments (e.g. net, boat, fishing basket etc.) (48\% $\pm 5 \%$ ) fishers took loan from the boat owner and money lender (dadondar) and were forced to work round the year in favor of them. The boat owners $(38 \% \pm 4 \%)$ took loans from aratdar (middle man) and had to pay repayment by selling fish to aratdar at fixed price and commission rate. Fishers also took loan $(52 \% \pm 4 \%)$ from NGOs with high interest. It was observed that fishers took loan from multiple NGOs at a time and repaid the installments of the loansfrom One NGO to another. Among the NGOs Grameen bank, BRAC, ASA, NUSA, SDS were found to work in this area (Table 5).

Table 5: Name of the loan provider NGOs

\begin{tabular}{ll}
\hline \multicolumn{1}{c}{ Name of NGOs } & \multicolumn{1}{c}{ Activities } \\
\hline Grameen bank & Micro-credit program \\
Bangladesh Rural Advancement Committee (BRAC) & Micro-credit program \\
Association for Social Advancement (ASA) & Micro-credit program \\
Naria Unnayan Samitty (NUSA) & Micro-credit program \\
Shariatpur Development Society (SDS) & Micro-credit program \\
& Child education program \\
\hline
\end{tabular}

\section{Vulnerabilities of the small-scale fishers}

Livelihood of this community mainly depended on hilsa fishing. Fishers caught hilsa mainly in January, February, May, August, September, October and December but income of fishers varied with seasonality that hampered the normal flow of livelihood. Food scarcity occurred during March and April and natural disasters become prominent during March, April, May and June. People of this community were very prone to natural calamities along with low income and lack of employment opportunities that hampered the resilience strategy to overcome the sufferings.

The main vulnerabilities reported by the fishers were ban periods, inadequate assistance during ban period, increasing fishing pressure, reduction in fish catches, creditor's pressure, weak value chain and poor market facility, loss of fishing equipments especially nets and boats during fishing etc. (Figure 03). Dependency on single profession made fishers' life more 
vulnerable ${ }^{4,37,38}$. Existing conflicts of the stakeholders like boat owner, money lender, also affects the stability of fishers' livelihood and allured to illegal fishing ${ }^{35,39,40}$.

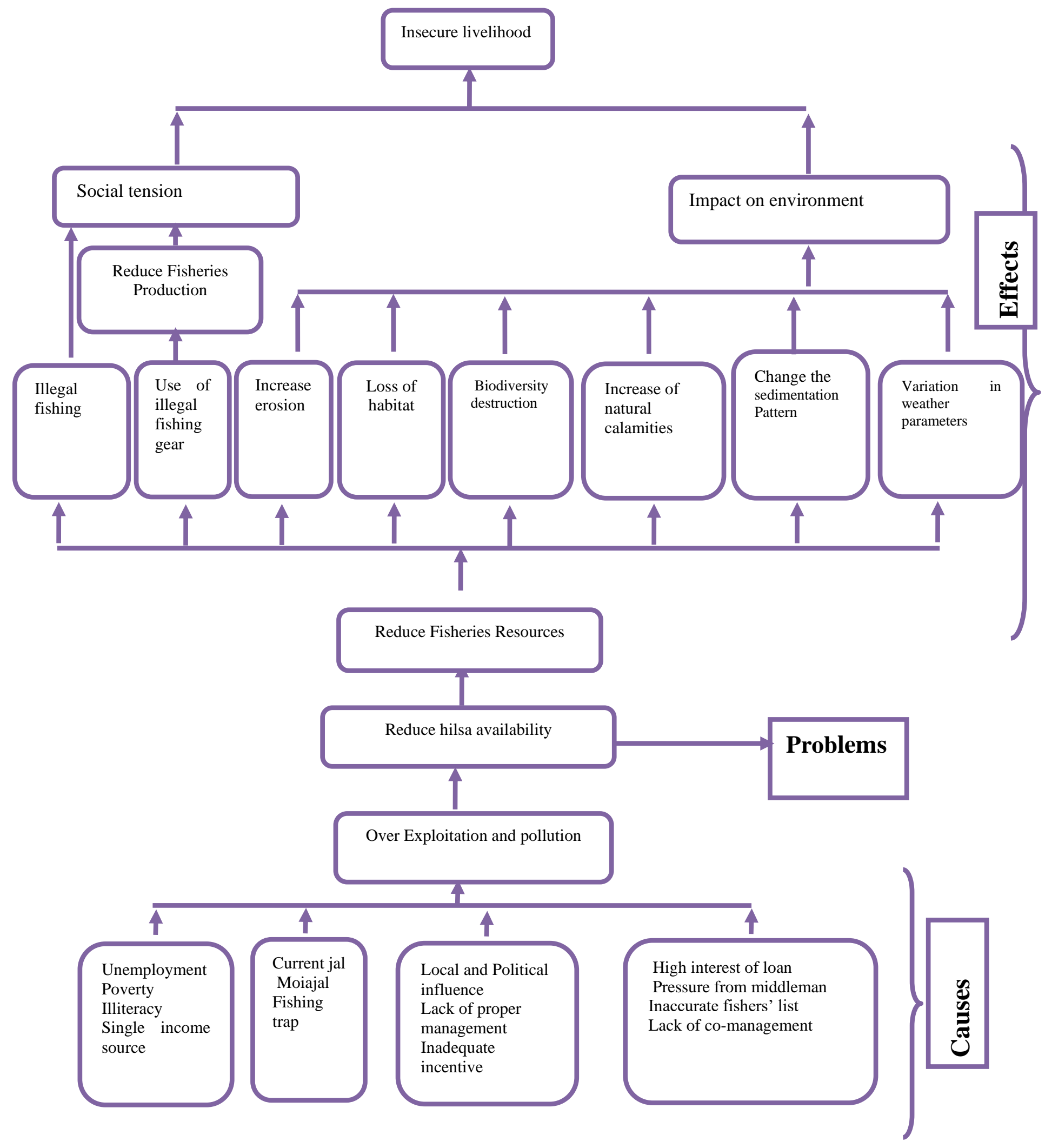


Figure 03: Vulnerabilities of small-scale fishers

\section{Conclusion and Recommendations}

In Bangladesh, the small-scale fishers were one of the most vulnerable communities in the society living with extreme rate of stratification, discrimination, social exclusion and economic domination. The pattern of their livelihood and living status was still below of average in the adjacent Padma and Meghna River. They were fully dependent on a single profession, economically insolvent and neglected. In addition, some socio-economic abstraction such as low income, credit insolvency, lack of substitute earning flexibility made them more vulnerable. To make their livelihood status better, some mandatory preamble should be taken. The government needs to ensure adequate assistance specifically financial support during the ban period and other unavoidable crises so that they could continue their profession. Government and affiliated NGOs should arrange training programs and skill developing seminars with knowledgeable and resource personnel for skill development of the fishers. Sustainable co-management, development of aquatic ecosystem, livelihood and vulnerability characteristics needs to be addressed by the policy-makers and researchers.

\section{References}

1. Sunny, A.R., Masum, K.M., Islam, N., Rahman, M., Rahman, A., Islam, J., Rahman, S., Ahmed, K.J., Prodhan, S.H. Analyzing livelihood sustainability of climate vulnerable fishers: Insight from Bangladesh. Journal of Aquaculture Research and Development. 2020a,11(6)

2. Sunny, A.R., Sazzad, S.A., Datta, G.C., Sarker, A.K., Ashrafuzzaman, M., Prodhan, S.H. Assessing Impacts of COVID-19 on Aquatic Food System and Small-Scale Fisheries in Bangladesh. Preprints 2020b, 2020060143,doi: 10.20944/preprints202006.0143.v1

3. DoF. Yearbook of Fisheries Statistics of Bangladesh, 2017-18. Fisheries Resources Survey System (FRSS), Department of Fisheries Bangladesh: Ministry of Fisheries, 2018. Volume 35 : p. 129

4. Sunny, A.R., Ahamed, G.S., Mithun, M.H., Islam, M.A., Das, B., Rahman, A., et al. Livelihood Status of the Hilsa (Tenualosa ilisha) Fishers: The Case of Coastal Fishing Community of The Padma River, Bangladesh. Journal of Coastal Zone Management. 2019, 22 (2):469

5. Sunny A.R., Hassan, M.N., Mahashin, M., Nahiduzzaman, M. Present status of hilsa shad (Tenualosa ilisha) in Bangladesh: A review. J.Entomol Zool Stud. 2017;5(6):2099-2105 
6. Yearbook of Fisheries Statistics of Bangladesh 2016-17. Fisheries Resources Survey System (FRSS), Department of Fisheries, Bangladesh: Director General, 129 (2017)

7. Sunny, A.R., Islam, M.M., Nahiduzzaman, M., Wahab, M.A. Coping with climate change impacts: The case of coastal fishing communities in upper Meghna hilsa sanctuary of Bangladesh. In: Babel, M.S., Haarstrick, A., Ribbe, L., Shinde, V., Dichti, N. (Eds.), Water Security in Asia: Opportunities and Challenges in the Context of Climate Change, Springer, 2018. ISBN 978-3-319-54612-4, at http://www.springer.com/us/ book/9783319546117

8. Islam, M.R., Cansse, T., Islam, M.S., Sunny, A.R. Climate change and its impacts: The case of coastal fishing communities of the Meghna River in south central Bangladesh. International Journal of Marine and Environmental Sciences.2018 doi: $10.5281 /$ zendo. 1474924

9. Mohammed, E.Y., Ali, L., Ali, S., Hussein, B., Wahab, M.A., Sage, N. Hilsa's nonconsumptive value in Bangladesh: Estimating the nonconsumptive value of the hilsa fishery in Bangladesh using the contingent valuation method. 2016; London.

10. Alok, K.P., Shapon, K.B., Mohammad, S.I., Hussain, M.A. Comparative socioeconomic study with a review on fisherman's livelihood around Tulsiganga River, Joypurhat, Bangladesh. Journal of Fisheries and Aquatic Science.2018.Doi:10.3923/jfas.2018

11. Rana, M.E.U., Salam, A., Shahriar, N.K.M., Hasan, M. Hilsa Fishers of Ramgati, Lakshmipur, Bangladesh: An Overview of Socio- Economic and Livelihood Context. Journal of Aquaculture Research\& Development. 2018;9:541

12. Milton, D.A. Status of Hilsa (Tenualosailisha) Management in the Bay of Bengal: An assessment of population risk and data gaps for more effective regional management, Report to FAO Bay of Bengal Large Marine Ecosystem Project, BOBLME, Phuket, Thailand, 2010

13. Mohammed, E.Y., Wahab, M.A. Direct economic incentives for sustainable fisheries management: The case of hilsa conservation in Bangladesh. IIED, London, 2013

14. Islam, M.M., Islam, N., Sunny, A.R., Jentoft, S., Ullah, M.H., Sharifuzzaman, S.M. Fishers' perceptions of the performance of hilsa shad (Tenualosailisha) sanctuaries in Bangladesh. Ocean \& Coastal Management, $2016 . \quad$ 130:309-316. DOi10.1016/j.ocecoaman.2016.07.003

15. Rahman, M.A., Flura, A. T., Pramanik, M.M.H., Alam, M.A. Impact of Fifteen Days Fishing Ban In The Major Spawning Grounds of Hilsa (TenualosailishaHamilton 1822) On Its Spawning Success. Res AgricLivest Fish. 2015;2(3):491-497 
16. Rahman, M.A., Pramanik, M.M.H., Flura, A. T., Hasan, M.M., Khan, M.H., Mahmud, Y. Impact Assessment of Twenty-Two Days Fishing Ban in the Major Spawning Grounds of Tenualosailisha(Hamilton, 1822) on its Spawning Success in Bangladesh. Journal of Aquaculture research Research and Development. 2017; 8(6):1-12

17. Islam, M.M., Mohammed, E.Y., Ali, L. Economic incentives for sustainable hilsa fishing in Bangladesh: An analysis of the legal and institutional framework. Marine Policy. 2016;68:8-22

18. Pritchett, L., Suryahadi, A., Sumarto, S. Qualifying Vulnerability to Poverty: A ProposedMeasure, Applied to Indonesia; The World Bank: Washington, DC, USA, 2000; Policy Research Working Paper No. 2437

19. Ellis, F. Rural Livelihoods and Diversity in Developing Countries; Oxford University Press: London, UK, 2000

20. DFID. Sustainable livelihoods guidance sheets. Department for International Development (DFID), London, UK. 1999

21. Schreckenberg, K., Camargo, I., Withnall, K., Corrigan, C., Franks, P., Roe, D., et al. Social assessment of conservation initiatives: a review of rapid methodologies. London: IIED. 2010

22. .Sunny, A.R., Reza, J., Anas, M., Hassan, M.N., Baten, M.A., Hasan, R., Monwar, M.M., Solaimoan, H., Hossain, M.M. Biodiversity assemblages and conservation necessities of ecologically sensitive natural wetlands of north eastern Bangladesh. Indian Journal of Geo-Marine Sciences. 2020. 49 (01)

23. Sunny, A.R., Alam, R., Sadia, A.K., Miah, Y., Hossain, S., Mofiz, S.B., et al. Factors affecting the Biodiversity and Human Well-Being of an Ecologically Sensitive Wetland of North Eastern Bangladesh. Journal of Coastal Zone Management. 2020, 23 (1):471

24. Khan, M.I, Islam, M.M., Kundu, G.K., Akter, M.S. Understanding the Livelihood Characteristics of the Migratory and Non-Migratory Fishers of the Padma River, Bangladesh. J Sci Res. 2018;10(3):261-273

25. Hasan, M.D., Ahsan, D.A. Socio-Economic Status of the Hilsa (Tenualosa ilisha) Fishermen of Padma River, Bangladesh. World Appl Sci J.2014;32(5): 857-864

26. Vaus, D. Surveys in Social Science Research, 5th Edition, Rutledge, London, 2002. 
27. Allison, E.H., Ellis, F. The livelihoods approach and management of small-scale fisheries. Marine Policy.2001; 25: 377-388

28. Kabir, K.M.R., Adhikary, R.K., Hossain, M.B., Minar, M.H. Livelihood Status of Fishermen of the Old Brahmaputra River, Bangladesh. World ApplSci J. 2012;16: 869873

29. Rahman, M., Rahman, M.M., Hasan, M.M., Islam, M.R. Livelihood status and the potential of alternative income generating activities of fisher's community of Nijhum Dwip under HatiyaUpaliza of Noakhali district in Bangladesh. Journal of Bangladesh Research Publications. 201;6:370-379

30. Minar, M.H., Rahman, A.F.M.A., Anisuzzaman, M. Livelihood status of the fisherman of the Kirtonkhola River nearby to the Barisal town. Journal of Agrofor Environ. 2012; 6:115-118

31. Ali, H., Azad, M.A.K., Anisuzzaman, Md., Chowdhury, M.M.R., Hoque, M., Shariful, M.I., et al. Livelihood Status of the Fish Farmers in Some Selected Areas of Tarakanda Upazila of Mymensingh District. Journal of Agroforestry and Environment. 2009;3(1):85-89

32. Islam, M.M., Islam, N., Mostafiz, M., Sunny, A.R., Keus, H.J., Karim, M., Hossain, M.Z., Sarker, S. Balancing between livelihood and biodiversity conservation: A model study on gear selectivity for harvesting small indigenous fishes in southern Bangladesh. Zoology and Ecology, 2018. doi:10.1080/21658005.2018

33. Zafar, S.M., Amin, N., Iqbal, M. J. Biodiversity of Fisheries organisms in the Pagla River of Bangladesh. Bangladesh J.Fish., 2007. 30 : 165-175

34. Kabir, K.M.R., Adhikary, R.K., Hossain MB, Minar MH. Livelihood Status of Fishermen of the Old Brahmaputra River, Bangladesh. World ApplSci J. 2012;16: 869-873

35. Islam, M.M., Shamsuzzaman, M.M., Sunny, A.R., Islam, N. Understanding fishery conflicts in the hilsa sanctuaries of Bangladesh. In: Inter-sectoral governance of inland fisheries.Song, A.M., Bower, S.D., Onyango, P., Cooke, S.J., Chuenpagdee, R. (eds.) 2017, pp18-31), TBTI Publication Series, St John`s, NL, Canada

36. Sunny, A.R., Islam, M.M., Rahman, M., Miah, M.Y., Mostafiz, M., Islam, N., Hossain, M.Z., Chowdhury, M.A., Islam, M.A., Keus, J.H. Cost effective aquaponics for food 
security and income of farming households in coastal Bangladesh. The Egyptian Journal of Aquatic Research.2019 doi.org/10.1016/j.ejar.2019.01.003

37. Mohammed, E.Y., Ali, L., Ali, S., Hussein, B., Wahab, M.A., Sage, N. Hilsa's nonconsumptive value in Bangladesh: Estimating the nonconsumptive value of the hilsa fishery in Bangladesh using the contingent valuation method. 2016; London

38. Rahman, M.J. Recent advances in biology and management of Indian shad (TenualosailishaHam.). SAARC Journal of Agriculture. 2006;4:67-90

39. Sunny, A.R. Impact of oil Spill in the Bangladesh Sundarbans. International Journal of Fisheries and Aquatic Studies.2017, 5 (5): 365-368

40. Islam, M.M., Sunny, A.R., Hossain, M.M., Friess, D. DRivers of Mangrove Ecosystem Service Change in the Sundarbans of Bangladesh. Singapore Journal of tropical geography.2018, doi:10.1111/sjtg.12241 